\title{
Biomarker suPAR seems a good prognostic factor for community-acquired pneumonia but less prominent for septic shock
}

\author{
Patrick M. Honore*, Aude Mugisha, Leonel Barreto Gutierrez, Sebastien Redant, Keitiane Kaefer, \\ Andrea Gallerani and David De Bels
}

We read with interest the article by Luo et al. [1]. The urokinase-type plasminogen activator system consists of a protease, a receptor urokinase-type plasminogen activator receptor (uPAR), and inhibitors [2]. Depending on the degree of glycosylation and proteolytic cleavage, soluble urokinase-type plasminogen activator receptor (suPAR) is a circulating protein ranging mostly between 20 and $35 \mathrm{kDa}$ [2]. Luo et al. show that suPAR exhibits high accuracy for both diagnosis and prognosis of severe community-acquired pneumonia (CAP) [1]. We would like to make some comments. While the area under the curve (AUC) for suPAR in order to accurately differentiate severe CAP (SCAP) from CAP is extremely good (AUC of $0.835(p<0.001)$ [1], it was reported poor regarding its ability to differentiate severity of sepsis shock (AUC of 0.62) [3]. An explanation could be that nearly half of critically ill patients especially with septic shock have or develop acute kidney injury (AKI) and 20-25\% needs renal replacement therapy (RRT) within the first week of their stay [4]. In the study of Luo, only 22 out of the 103 SCPA patients were in septic shock, so the rate of AKI and CRRT was much lower in Luo's cohort when compared to a full septic shock cohort [4]. Continuous RRT (CRRT) is performed using membranes that have a cut value of $35-40 \mathrm{kDa}$, and therefore, some quantity of suPAR will be eliminated [5]. New highly adsorptive membranes (HAM) that can adsorb many molecules with a molecular weight above $35 \mathrm{kDa}$ will even increase this removal [5]. This can mislead patient prognostication by artificially decreasing suPAR, but no studies have challenged this issue. Such studies should be done as there is already a long list of biomarkers in sepsis that are lacking reliability during CRRT [5]. To date, no

\footnotetext{
* Correspondence: Patrick.Honore@CHU-Brugmann.be

This comment refers to the article available at https://doi.org/10.1186/ s13054-018-1943-y.

ICU Department, Centre Hospitalier Universitaire, Place Van Gehuchtenplein,4, 1020 Brussels, Belgium
}

single sepsis biomarker can be reliable during CRRT. While suPAR might be a good marker of severity in SCAP, this might not be the case for septic shock. A hypothesis that could explain this discrepancy could be the rate of CRRT use in this group of patients that is much higher as compared to SCAP in the Luo's study. As a consequence of the high CRRT rate, suPAR levels are no longer reliable in septic patients [1].

\section{Abbreviations \\ UPAR: Urokinase-type plasminogen activator receptor; suPAR: Soluble urokinase-type plasminogen activator receptor; CAP: Community acquired pneumonia; SCAP: Severe community-acquired pneumonia; AUC: Area under the curve; AKI: Acute kidney injury; RRT: Renal replacement therapy; CRRT: Continuous renal replacement therapy; HAM: Highly adsorptive membranes}

\section{Acknowledgements}

None.

Authors' contributions

$\mathrm{PMH}$ and DDB designed the paper. All authors participated in drafting and reviewing. All authors read and approved the final version of the manuscript.

\section{Funding}

None.

Availability of data and materials

Not applicable.

Ethics approval and consent to participate Not applicable.

\section{Consent for publication}

Not applicable.

\section{Competing interests}

The authors declare that they have no competing interests.

Received: 10 September 2019 Accepted: 4 December 2019 Published online: 11 December 2019

\footnotetext{
References

1. Luo Q, Ning P, Zheng Y, Shang Y, Zhou B, Gao Z. Serum suPAR and syndecan-4 levels predict severity of community-acquired pneumonia: a prospective, multi-centre study. Crit Care. 2018;22(1):15.
} 
2. Thuno M, Macho B, Eugen-Olsen J. suPAR: the molecular crystal ball. Dis Markers. 2009;27(3):157-72.

3. Koch A, Voigt S, Kruschinski C, Sanson E, Dückers H, Horn A, et al. Circulating soluble urokinase plasminogen activator receptor is stably elevated during the first week of treatment in the intensive care unit and predicts mortality in critically ill patients. Crit Care. 2011;15:R63.

4. Peters E, Antonelli M, Wittebole X, Nanchal R, François B, Sakr Y, et al. A worldwide multicentre evaluation of the influence of deterioration or improvement of acute kidney injury on clinical outcome in critically ill patients with and without sepsis at ICU admission: results from The Intensive Care Over Nations audit. Crit Care. 2018;22(1):188. https://doi.org/ 10.1186/s13054-018-2112-z.

5. Honoré PM, Jacobs R, De Waele E, Van Gorp V, Spapen HD. Evaluating sepsis during continuous dialysis: are biomarkers still valid? Blood Purif. 2014;38(2):104-5. https://doi.org/10.1159/000363497 Epub 2014 Oct 17.

\section{Publisher's Note}

Springer Nature remains neutral with regard to jurisdictional claims in published maps and institutional affiliations. 